\title{
Pengolahan Ampas Sagu Menjadi Kompos dan Kue Kering dari Tepung Sagu
}

\author{
Gunawan $^{1^{*}}$ dan Muhammad Mahfuzh ${ }^{2}$ \\ ${ }^{1}$ Prodi Biologi, FMIPA Unlam \\ ${ }^{2}$ Prodi Matematika, FMIPA Unlam \\ J1. A. Yani, Km 36, Banjarbaru, Kalimantan Selatan \\ *Korespondensi penulis, email: ggunlam@gmail.com
}

\begin{abstract}
Abstrak: Tepung sagu memiliki potensi yang besar untuk diolah menjadi produk makanan. Demikian juga dengan ampas sagu dapat dimanfaatkan menjadi pupuk kompos. Namun potensi yang besar belum sepenuhnya dikembangkan. Melalui kegiatan KKN-PPM para ibu-ibu rumah tangga di desa Pemakuan, kecamatan Sungai Tabuk telah dilatih untuk membuat kompos dari ampas sagu dan aneka kue kering dari tepung sagu. Hasil kegiatan menunjukkan pemakaian pupuk kompos untuk pertanian telah menurunkan biaya pemupukan sebesar $30 \%$. Selain itu terdapat peningkatan pendapatan sebesar Rp. 800.000 pada keluarga yang membuat aneka kue kering dari tepung sagu.
\end{abstract}

Kata Kunci: Tepung sagu, ampas sagu, kue kering, kompos

\section{PENDAHULUAN}

Sagu memiliki potensi yang paling besar untuk digunakan sebagai pengganti beras. Pohon sagu dapat tumbuh dengan baik di rawa-rawa dan pasang surut, dimana tanaman penghasil karbohidrat lainnya sukar tumbuh.

Desa Pemakuan, Kecamatan Sungai Tabuk, Kabupaten Banjar merupakan salah satu sentra pengolahan pengolahan sagu. Dalam pengolahan sagu, selain dihasilkan tepung sagu juga dihasilkan beberapa limbah sagu yaitu limbah padat dan limbah cair. Namun demikian, meskipun menjadi sentra pengolahan sagu, ternyata tepung sagu yang dihasilkan belum dimanfaatkan secara optimal, demikian juga limbahnya hanya dibuang begitu saja ke sungai.
Tepung sagu memiliki potensi yang sangat besar untuk dikembangkan menjadi bahan pangan alternatif karena dari aspek nilai gizi tepung sagu mempunyai beberapa kelebihan dibanding tepung dari tanaman umbi atau serelia (Jong dan Widjono, 2005). Produk-produk makanan sagu tradisional dikenal dengan nama papeda, sagu lempeng, buburnee, sagu tutupala, sagu uha, sinoli, bagea, dan sebagainya. Limbah batang sagu dapat diolah menjadi briket untuk industri kimia, bahan bakar, medium jamur, hard board, kompos dan sebagainya (Widowati 2001).

Untuk memaksimalkan potensi sagu dan meningkatkan pendapatan masyarakat terutama petani sagu, Fakultas MIPA ULM 
melalui kegiatan KKN-PPM melakukan pendidikan dan pelatihan (life skills) untuk para istri petani sagu untuk membuat aneka olahan berbasis tepung sagu dan pengolahan limbah sagu menjadi pupuk kompos yang bernilai ekonomi, untuk meningkatkan pendapatan keluarga.

\section{METODE PELAKSANAAN}

Pengolahan kompos dari ampas sagu dan kue kering dari tepung sagu dilaksanakan melalui pelatihan, penyuluhan dan praktek langsung, pembuatan komposter, serta pembuatan label. Selain itu, tim pelaksana juga menjalin kerja sama dengan Dinas Perindustrian dan Perdagangan Kab. Banjar dan mini market serta toko oleh-oleh untuk memperluas pemasaran.

\section{HASIL KEGIATAN}

\section{A. Kompos dari ampas sagu}

$$
\begin{aligned}
& \text { Industri ekstraksi pati sagu selain } \\
& \text { menghasilkan tepung sagu juga } \\
& \text { menghasilkan limbah. Tiga jenis limbah } \\
& \text { yang dihasilkan yaitu residu selular empelur } \\
& \text { sagu berserat (ampas), kulit batang sagu dan } \\
& \text { air buangan (waste water). Pada umumnya, } \\
& \text { jumlah kulit batang sagu dan ampas sagu } \\
& \text { berturut-turut sekitar } 26 \% \text { dan 14\% berdasar } \\
& \text { bobot total balok sagu (Kiat, 2006). Limbah }
\end{aligned}
$$

ampas sagu merupakan bahan yang mengandung lignoselulosa yang sebagian besar tersusun atas selulosa, hemiselulosa dan lignin. Limbah padat industri sagu dapat dimanfaatkan sebagai penyedia unsur hara untuk pertumbuhan tanaman (Sutejo, 2002).

Kompos dari ampas sagu dapat dibuat dengan mencampurkan ampas sagu dengan kompos yang sudah matang atau dengan kotoran ternak, dengan komposisi ampas sagu 50-75\% (Firmansyah, 2010). Pembuatan kompos dari ampas sagu dapat menggunakan komposter (Gambar 1.) atau ditimbun d idalam tanah. Campuran ampas sagu dan kompos yang sudah matang atau kotoran ayam yang telas dimasukkan ke dalam komposter atau ditimbun harus dibolak balik setiap 3-4 hari sekali, hal ini bertujuan agar proses pematangan kompos merata. Untuk mempercepat pematangan dapat juga ditambah EM4 dengan cara disemprotkan. Kompos dapat dipanen dalam waktu 3-4 mingu. Setyorini et al. (2011) menyebutkan bahwa warna kompos yang telah matang akan berbeda dengan warna bahan-bahan mentahnya dan lebih menyerupai warna tanah. 


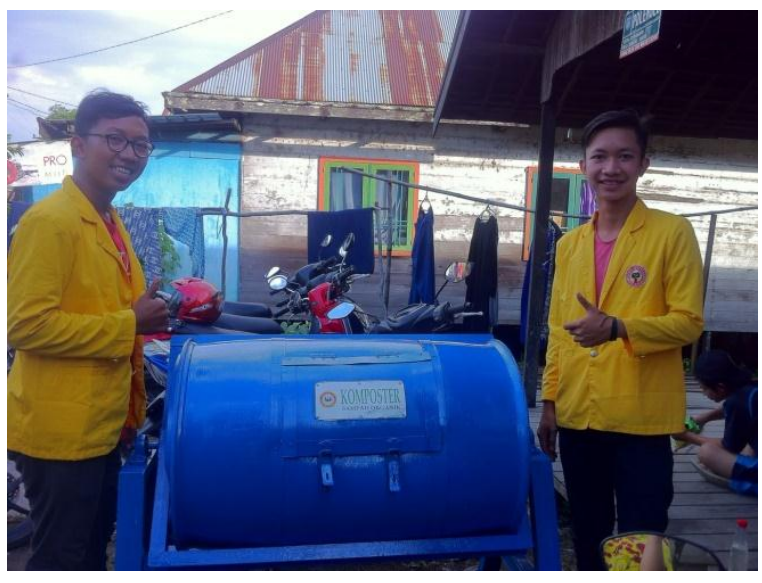

Gambar 1. Komposter sederhana

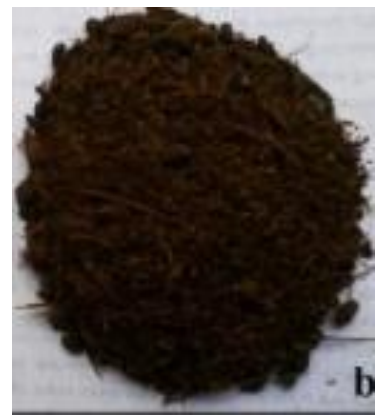

Gambar 2. Kompos dari ampas sagu yang sudah matang.

Hasil analisa kompos ampas sagu di Laboratorium FMIPA ULM ditunjukkan pada Tabel 1 .

Tabel 1. Hasil analisis C, N, P dan K pada kompos ampas sagu.

\begin{tabular}{|l|l|}
\hline \multicolumn{1}{|c|}{ Unsur } & \multicolumn{1}{c|}{ Jumlah } \\
\hline $\mathrm{C}$ (karbon) & $21,63 \%$ \\
\hline $\mathrm{N}$ (Nitrogen) & $1,36 \%$ \\
\hline $\mathrm{P}$ (phospor) & $1,25 \%$ \\
\hline K (Kalium) & $1,36 \%$ \\
\hline C/N rasio & 15,9 \\
\hline
\end{tabular}

Hasil analisa menunjukkan bahwa persentase kandungan unsur yang ada di dalam kompos ampas sagu masih sesuai dengan yang ditetapkan oleh SNI. Contohnya adalah Rasio $\mathrm{C} / \mathrm{N}$ yang masih didalam ambang batas yang ditetapkan oleh SNI. Rasio C/N adalah salah satu parameter penting untuk mengetahui kualitas kompos. Rasio ini digunakan untuk mengetahui apakah kompos sudah cukup 'matang' atau belum. Rasio $\mathrm{C} / \mathrm{N}$ ini juga diatur di dalam SNI $19-7030$ - 2004 tentang kualitas kompos. Di dalam SNI rasio $\mathrm{C} / \mathrm{N}$ kompos yang diijinkan adalah $10-20$ (Pramaswari et.al., 2011).

\section{B. Kue kering dari tepung sagu}

Tepung sagu dapat digunakan untuk bahan pangan yang lebih komersial seperti roti, biskuit, mie, sohun, kerupuk, hunkue, bihun, dan sebagainya (Jong dan Widjono, 2005).

Kue kering sagu yang dibuat pada kegiatan KKN-PPM mahasiswa FMIPA ULM diantaranya adalah kue telunjuk sagu (Gambar 3) dan aneka kue semprit sagu (Gambar 4). Untuk membuat 1 resep kue telunjuk sagu bahan-bahannya adalah tepung sagu $1 \mathrm{Kg}$, penyedap rasa 2 bungkus, keju parut $1 / 4$ bungkus, margarine 2 bungkus, telur 5 butir dan vanili 2 buah. 


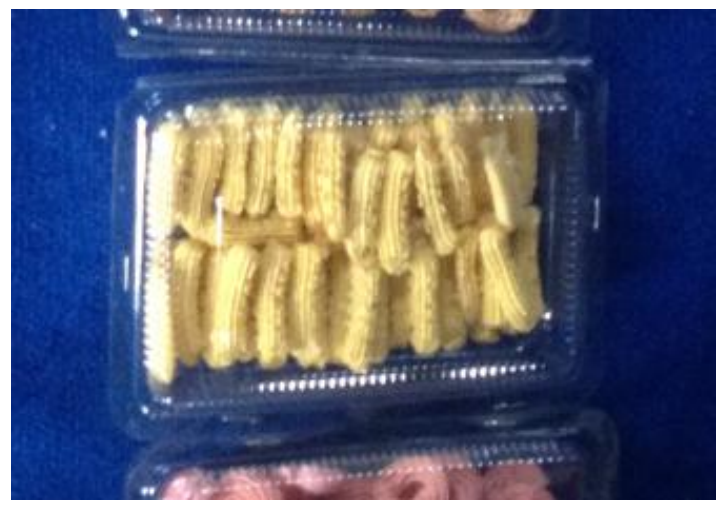

Gambar 3. Kue telunjuk dari tepung sagu

Cara pembuatan: kocok margarine, vanili, dan penyedap rasa hingga putih masukkan telur satu per satu sambil dikocok, masukkan tepung sambil diaduk dengan tangan, taburi keju, aduk kembali sampai rata, kemudian cetak dan oven.

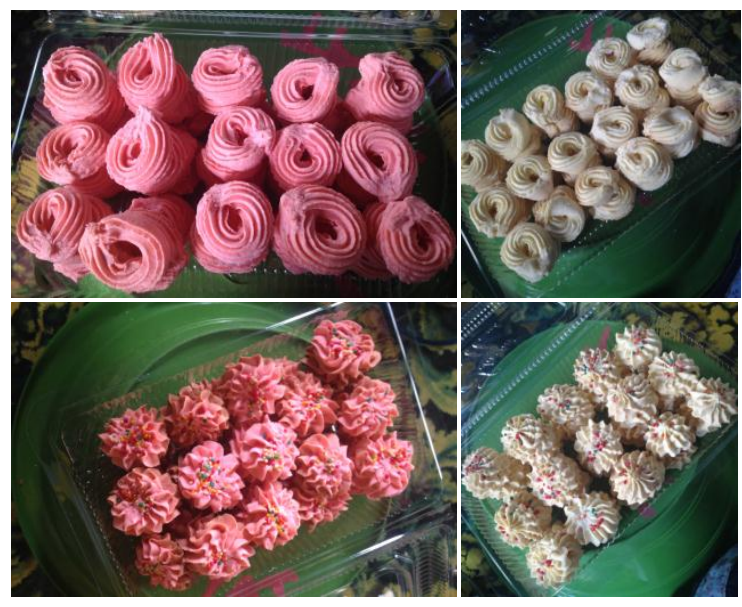

Gambar 4. Kue semprit dari tepung sagu Bahan-bahan untuk membuat kue semprit adalah tepung sagu $1 \mathrm{~kg}$, telur 2 butir (penuh), kuning telur 4 butir, margarine 2 bungkus, gula halus 4 ons, butter $2 \mathrm{sdm}$, dan vanili 2 buah. cara membuat nya adalaha: kocok margarine, vanili dan butter hingga putih, masukkan telur satu per satu sambil dikocok, masukkan tepung sambil diaduk dengan tangan, masukkan gula halus, aduk kembali sampai merata, kemudian cetak dan oven.

Kandungan kalori pati sagu setiap 100 gram ternyata tidak kalah dibandingkan dengan kandungan kalori bahan pangan lainnya. Perbandingan kandungan kalori berbagai sumber pati adalah (dalam $100 \mathrm{~g}$ ): jagung 361 Kalori, beras giling 360 Kalori, ubi kayu 195 Kalori, ubi jalar 143 Kalori dan sagu 353 Kalori (Flach dan Rumawas, 1996).

Tabel 1. Kandungan gizi tiap 100 gram sagu kering, setara dengan 355 kalori

\begin{tabular}{|l|c|}
\hline \multicolumn{1}{|c|}{ Kandungan Gizi } & Jumlah (gram) \\
\hline Karbohidrat (pati) & 94 \\
\hline Protein & 0,2 \\
\hline Lemak & 0,5 \\
\hline Kalsium & 10 \\
\hline Besi & 1,2 \\
\hline Karotin & Dalam jumlah kecil \\
\hline Tiamin & Dalam jumlah kecil \\
\hline Asam askorbat & Dalam jumlah kecil \\
\hline
\end{tabular}

(Flach dan Rumawas, 1996).

Dari hasil survey setelah pelaksanaan kegiatan, terdapat 8 orang petani yang sudah memanfaatkan kompos dari ampas sagu tersebut, penggunaan kompos telah mengurangi $30 \%$ biaya pemupukan. 
Sedangkan untuk kue kering dari tepung sagu yang disurvey pada 4 orang ibu rumah tangga yang membuat kue kering terdapat peningkatan pendapatan sebesar Rp. 800.000. Tepung sagu mentah dihargai Rp. 5000, namun jika sudah diolah menjadi kue kering harga per 400 gram kue kering dari tepung sagu mencapai Rp. 30.000-40.000, sungguh penambahan nilai jual yang luar biasa.

Pemakaian pupuk kompos dari limbah sagu, selain dapat mengurangi pencemaran lingkungan akan mengurangi pengeluaran petani untuk membeli pupuk sebesar 30\%. Pemakaian pupuk kimia dalam pertanian memang tidak dapat dihindari, karena pupuk kimia lebih cepat menunjukkan hasil yang diinginkan. Oleh karena itu, penggunaan pupuk kompos hanya sebagai campuran pemupukan tanaman.

Pembuatan kue kering dari tepung sagu juga akan memberikan pendapatan tambahan bagi petani sagu. Modal pembuatan kue kering sagu adalah Rp. 100.000, dengan asumsi menggunakan $2 \mathrm{~kg}$ tepung sagu, akan menghasil $2 \mathrm{~kg}$ kue kering sagu. Jika tiap 400 gram kue kering dijual Rp. 35.000 maka akan mendapatkan hasil penjulan Rp. 175.000. Sehingga usaha kue kering tiap $2 \mathrm{~kg}$ sagu akan mendapatkan keuntungan sebesar Rp. $\quad$ 75.000.

Berdasarkan hasil survey pembuatan kue kering dari tepung sagu dapat memberikan tambahan pendapatan bersih sebesar $\mathrm{Rp}$. 800.000 per bulan.

\section{KESIMPULAN}

Pengolahan ampas sagu menjadi kompos dapat dilakukan dengan komposter atau dipendam dalam tanah, untuk mempercapat proses pengomposan dapat dicampurkan kompos yang sudah matang atau kotoran ayam atau sapi dengan komposisi 50-75\%. Kompos dapat dipanen 3-4 minggu. Dari hasil kegiatan pengolahan kompos dapat mengurangi biaya pemupukan sebesar $30 \%$ bagi para petani.

Pembuatan kue kering dari tepung sagu dapat meningkatan nilai ekonomi tepung sagu. Selain itu, dapat memberikan tambahan pendapat sebesar Rp. 800.000 per bulan untuk petani sagu.

\section{DAFTAR PUSTAKA}

Firmansyah MA. 2010. Teknik Pembuatan Kompos. Pelatihan Petani Plasma Kelapa Sawit di Kabupaten Sukamara, Kalimantan Tengah.

Flach, M. dan F. Rumawas, eds. 1996. Plant Resources of South-East A sia (PROSEA) No.9: Plants Yielding Non-Seed Carbohydrates. Leyden. Blackhuys 
Jong dan Widjono, 2005. Kandungan gizi tepung sagu. Penebar Swadaya

Kiat L.J, 2006. Preparation and Characterization of Carboxymethyl Sago Waste and It's Hydrogel [tesis]. Malaysia: University Putra Malaysia.

Pramaswari, I.A.A., Suyasa, I.W.B., dan

Putra, A.A.B. 2011. Kombinasi Bahan

Organik (Rasio C : N) pada

Pengolahan Lumpur (Sludge) Lim bah

Pencelupan. Jurnal Kimia 5 (1) : 64 -

71.

Setyorini Diah, Saraswati R, Anwar EK. 2011. Kompos. Pupuk Organik dan Pupuk Hayati : 11-40.

Sutejo, M.M. 2002. Pupuk dan Cara Pemupukan. Rineka Cipta. Jakarta.

Widowati. 2001. Sumber Karbohidrat pendamping Beras dan terigu. Teknik Produksi Aneka Tepung dan Pati dari bahan Pangan sumber Karbohidrat serta Potensi Pemanfaatannya. Makalah disampaikan Pada alih Teknologi Produksi aneka Tepung dan pemanfaatannya dalam rangka Menunjang Ketahanan Pangan. Penerbit : Balitkabi, malang. 17 oktober 2001. 